removed for us some of its then-to-fore insuperable disadvantages, and now, of course, all good and competent anæsthetists recognise its use and value. We cannot admit, however, that it is either so safe, so convenient, so universally applicable or so agreeable, even when most skilfully administered, as its almost perfect sister, chloroform; and, I believe, we agree almost to a man entirely with Sir George Mcleod. We have to thank Mr. Teale for reverting to the subject in his address in the Surgical Section at Leeds last week, and for giving us the result of his experience, though it took the form of a sort of counterblast in favour of ether

The experiences of these two authorities are as widely different, as are their conclusions. Let me recall what Sir George McLeod said at Glasgow last year. He said, that "for speed and energy, for ease of application and agreeableness, for rapid recovery with little subsequent trouble, and for safety when properly administered, chloroform is unrivalled." Mr. Teale this year, ex êdem cathedrâ, lays down that ether, if properly administered, can be given, tute, cito, et jucunde; but, quotes $\mathrm{Mr}$. Teale, "non cuivis homini contingit adire Corinthum," and this he translates, for the benefit of his hearers, " it is not every one who knows, and there are some who are incapable of learning, how to administer ether, even with a Clover's inhaler." Let me ask, if this quotation is so applicable to etherists, surely is it not much more applicable to chloroformists? And, in argument, ought it not to be applied, in justice, equally to both? Many times since ether became in vogue have I witnessed its administration at the hands of old and young. With few exceptions, and as a rule, the exhibition has been painful in the extreme, and to those who know how ether should be administered, and who know also the virtues of chloroform, it is not too much to say barbarous and reprehensible. Tutus it certainly is not. And I believe the patients when they tell me, as they almost daily do, that the process is very far indeed from jucundus. Nearly every day patients declare to me their aversion to ether and their preference for chloroform. In my own practice I very frequently come across those who caunot take ether, however carefully and skilfully administered. Perhaps I see more than my share of these, for it is well known that I never yet have refused chloroform to anyone. As to the cito, the "saving of time," I say, without fear of contradiction, that time is a factor which a competent anæsthetist never dares to take into consideration.

Mr. Teale speaks of the "comfort and convenience" it has been to him while operating since he allowed his assistants to give ether to his patients instead of chloroform. My only answer to this is that an operating surgeon has omitted part of his duty if he has failed to secure the services of a competent anæsthetist for an operation ; and if he has done his duty to himself and patient in this respect, I fail to see where the question of "comfort and convenience" to him comes in. Dr. Joy Jeffreys in 1872 , we are reminded by $\mathrm{Mr}$. Teale, nrged the "fearfully increasing fatality of chloroform." 'This, at the time, as reference to the medical journals of the date will show, was, to say the least, a great exaggeration, and each year's experience since has given it an ever-increasing refutation. The alarmists, who do such incalculable harm by their cry that "ether is safe, chloroform is dangerous," utterly ignore the fact that in this island alone chloroform is given every day to at least from 1500 to 2000 individuals, or, say, to about 600,000 per annum. And how rarely do we hear of a death under it ; from it almost never. For five-and-twenty years $I$ have never, on any one single occasion, refused chloroform to anyone, and I have given it to those suffering from all forms and conditions of bodily disease-of head, heart, lungs, kidneys, and all other viscera. With my own hands I have given it to not less than 5000 of my fellow-creatures, and have witnessed its administration by others hundreds of times. I give chloroform, or ether preceded by chloroform, as part of my everyday routine, where pain may be thereby remitted, on every possible occasion. It has not yet been my misfortune to witness a fatality under any anresthetic, but $I$ deem it right to be ever expectant that the dread disaster may one day befal ne. Yet I venture in all humility to hope that, should it ever happen, neither I nor the drugs may be justly held blamable, and that my confidence in the use of my trusted agents for the relief of pain may be by such an accident in no degree impaired. Of the many advantages of chloroform, there is one, and not the least, which has received too little attention-namely, that with it we are enabled to rob ether of its terrors, terrors most real indeed to those (and they are not a few) whose nature revolts against its nauseous flavour, and to whom the sense of suffocation so frequently attendant on its inhalation, no matter how carefully or how skilfully administered, is absolutely unbearable.

I entirely agree with Sir George McLeod's verdict in favour of chloroform, yet on many main points $I$ have little doubt that $\mathrm{Mr}$. Teale and I would be found in perfect accord. My general view is, that the $\pi \rho a_{\zeta}$ s of all anæsthetic-giving is simple enough, and easily acquired. Not so the $\dot{\epsilon} \pi \sigma \tau \tau^{\prime} \mu \eta$ and the $\tau \chi^{\nu} \eta$. As in all higher crafts, the first is easily taught; the second can be taught in part only; but the third, the $\tau \epsilon ́ \chi^{\nu \eta}$, cannot be taught, and can only be acquired by long experience and natural aptitude. Very easily, and with fairly diligent observance of detail and practice, the

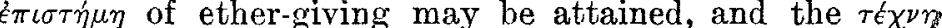
is now acquired by not a few. But to become an artist in the administration of chloroform, more practice, sounder judgment, keener and more rapid power of observation, and more aptitude, are requisite and essential.

I am, Sirs, yours obediently,

Leeds, Aug. 17th, 1889. JOHN HORSFALL.

\section{"FUNCTIONAL ALBUMINURIA."}

\section{To the Editors of THE LANCET.}

SIRs,-By an apparently clerical, but still not unimportant, error in the report of the discussion on albuminuria at Leeds, you have made me say that "Dr. Gairdner was still unconvinced that we could talk of functional albuminuria." What I really said was that physiological albuminuria is, in my opinion, both an inaccurate and a misleading expression; but that I did not so much object to the provisional term functional albuminuria, subject to the construction of it given in your report. The essence of my remarks was contained in the phrase you have quoted in your leading article-viz., that albumen, meaning thereby serum-albumen cognisable by the heat and nitric acid tests, even when casually occurring in the urine, is to be regarded as a kind of danger-signal; but that the danger may vary indefinitely in different cases, and is to be estimated according to principles very well expounded by Dr. Pavy and other speakers, but implying always, in proposals of life insurance, a postponement at least, to allow of more detailed and, in some cases, frequently repeated observations, in respect of which the proposer's own medical attendant mays often be advantageously informed of the facts.

I am, Sirs, yours truly,

Glasgow, Aug. 24th, 1889 W. T. GAIRDNER.

\section{THE USE OF ROBURITE IN MINES. To the Editors of THE LANCET.}

SIRs,-Before Major-General W. H. Wardell had come to the following conclusion-namely, "while expressing my surprise that the writer of your article should have followed the miners' committee in misreading the report of the experts, \&c.," -it would have been well if he himself had not misread the same report, and had also searched for other reports of the poisonous nature of roburite or di-nitro-benzol. I need only here notice that he states it was proved at the inquest on the man who unfortunately met with his death at the Roburite Works at Gathurst "that the poor man died from the effects upon a weak heart, \&c." He then goes on to say "that other healthy men had repeatedly done the same withont receiving any sensible harm," whereas at the inquest there was no evidence of the deceased having a weak heart previously to the poisoning, and, again, that the other men had sensibly suffered from cleaning this very flue, and every precaution was laid down for them, and the men were paid double for doing this dangerous work, as well as only allowed to remain a short time in the flue, showing that the authorities knew of the danger the men were sub. mitting to.

I would respectfully call the attention of Major-General Wardell to the following articles which have appeared lately in the medical papers:-On Poisoning by Roburite, by J. Ross, M.D., LL.D., F.R.C.P. Lond.; on Acute Poisoning by Nitro-Benzol, by Dr. Reynolds, M.R.C.P. Lond. (Manchester Medical Chronicle for May); on the Effects of Nitro-Benzol, by R. Prosser White, M.B. (Yractitioner for June); Case of Poisoning by New "Sicherheit" Explosive, by William Sykes, M.R.C.S., and F. Gramshaw 